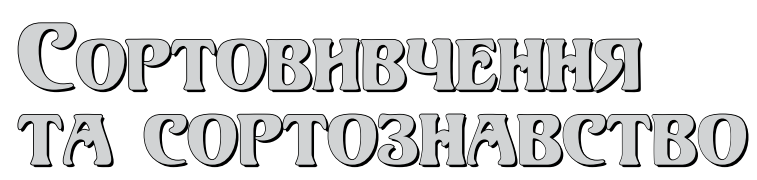

UDC 631.526.1/8:262:635.71(477.46)

https://doi.org/10.21498/2518-1017.17.4.2021.248975

\title{
Adaptive variability of basil (Ocimum basilicum L.) varieties
}

\author{
I. 0. Kucher \\ Uman National University of Horticulture, 1 Instytutska St., Uman, Cherkasy region, 20305, Ukraine, \\ e-mail:inna.kucher95@gmail.com
}

Purpose of the research was to estimate the state of varietal resources and adaptive-and-productive potential of basil plants. Methods. Field, laboratory, statistical and calculation-analytical. The field work included marking out of the experimental plot and field work. The laboratory method was used to analyze plants, assess the quality of the crop, and study physical, chemical and microbiological properties of the soil. Statistical and analytical calculation methods were used to calculate the results. Results. The varieties of 'Temnyi Opal', 'MFI-2', 'Siaivo' and 'Badioryi' where the regression coefficient was in the range of $0.57-0.78$ can be included to the group of highly plastic varieties by the "commodity yield" feature according to the results of research. The highest rate of breeding value by the "plant weight" trait was observed in the variety of 'Temnyi Opal', Sc = 347.22. The group of highly plastic varieties on the basis of "plant weight" trait included the varieties 'Mister Barns', 'MFI-2', 'Rutan', 'Siaivo' and 'Badioryi', where the regression coefficient was in the range of 0.91-0.99. The varieties 'Temnyi Opal', 'Yerevanskyi', 'Ametyst' and 'Lymonnyi Aromat' were classified as intensive. The regression coefficient of these varieties was in the range of 1.03-1.16. The analysis of the combination of high productivity, quantitative characteristics of the crop structure with the level of ecological plasticity and stability indicates different ways of these indicators formation in separate varieties. It was revealed that a high level of plasticity and yield stability did not guarantee a similar result on some quantitative features of its structure. Conclusions. The degree of adaptability of basil varieties can also be assessed by the value of the parameters of features variation. The obtained results will allow more objectively assessing the adaptive-and-productive potential of varieties and qualitatively selecting initial forms for further breeding for adaptability.

Keywords: adaptive ability; stability; plasticity; morphometric parameters; yielding capacity.

\section{Introduction}

The rate of consumption of spicy-aromatic vegetables per year per person in Ukraine should be $1.7 \mathrm{~kg}$ [1]. According to other data, in the average annual norm of vegetable consumption of $161 \mathrm{~kg}$ per capita, the share of spicyaromatic vegetables should be about $2.4 \mathrm{~kg}$, including about $1.0 \mathrm{~kg}$ in the off-season period [2]. Other authors also support the consumption rate of $1.7 \mathrm{~kg}$ per year, including $0.4 \mathrm{~kg}$ from greenhouses [3]. At the advice of the medical doctor, a person should consume $2 \mathrm{~kg}$ of spicy-aromatic vegetables per year, of which $1.5 \mathrm{~kg}$ should be grown in open ground, and $0.5 \mathrm{~kg}$ in greenhouses [4].

In view of the prospects of using and the efficiency of cultivation, basil (Ocimum basilicum L.) deserves special attention, although

Inna Kucher

https://orcid.org/0000-0002-2864-5252 now its plantings are very few [5]. Cultivation of the genus Ocimum L. is growing all over the world due to its pharmaceutical and nutraceutical value, as well as easy adaptation to different soil and climatic conditions [6].

An important feature of basils is their unpretentiousness to agro-climatic growing conditions. However, basils in Ukraine occupy insignificant areas. Usually they are grown by amateurs and certain processing enterprises [7]. In recent years, there has been a positive trend towards an increase in the species and varietal composition of basils to fill the market with their own high-quality plant raw materials and products [8]. Extension of the existing assortment of basils is constrained by insufficient knowledge of varietal diversity, the biology of new and less common varieties, and the lack of the required amount of seed and planting material [9].

Therefore, the analysis of the prospects for basil species growing, the study of their varietal diversity is relevant and important both 
for the Right-Bank Forest-Steppe of Ukraine, since this soil-climatic zone is one of the most promising for growing aromatic plants, and for Ukraine as a whole.

The aim of the research was a comprehensive assessment of the state of varietal resources and the potential of basils in the conditions of the Right-Bank Forest-Steppe of Ukraine.

\section{Materials and methods}

The research was conducted in 2019-2021 on the experimental field of Uman National University of Horticulture. The relief of the experimental field was flat with a slope in the southern direction. The soil of the experimental plot is chernozem podzolic hard loam with a well-developed humus horizon (about 3\%). The following varieties of basil were studied: 'Badioryi', 'Temnyi Opal', 'Yerevanskyi', 'Ametyst', 'Mister Barns', 'Lymonnyi Aromat', 'MFI-2', 'Rutan', 'Siaivo'. 'Badioryi' variety served as a control, as at the time of the research it was the most tested and for the longest time was in the State Register of Plant Varieties Suitable for Distribution in Ukraine. Varieties 'Badioryi', 'Siaivo' and 'Rutan' are included in the Register of Plant Varieties of Ukraine. The originator of 'Badioryi' variety is «Nasko» agricultural company; «Maiak» Experimental Station of the Institute of Vegetable and Melon Growing is the originator of 'Rutan' and 'Siaivo' varieties. Given biometric parameters of basil plants were studied: plant height, leaf area, number of leaves, number of first order tillers. A randomized field experiment was conducted. The experiment was performed in four repetitions. The experimental plot measured $10 \mathrm{~m}^{2}$, with 67 basil plants on it. The cassette method of growing seedlings was used with a cell size of $6 \times 6 \mathrm{~cm}$. Seedlings were planted with a spacing of $50 \times 30 \mathrm{~cm}$. Morphological parameters were measured in 40 marked plants, 10 plants in repetition.

Statistical processing of results. Mathematical processing was carried out by the method of dispersion analysis. The coefficient of linear regression of the yield of a variety shows its response to changing growing conditions. The higher was the value of the coefficient (bi), the better was the response of the variety. In the case of $b i<1$, the variety reacted poorly to changing environmental conditions. When $b i=1$, there was a complete correspondence between the change in the yield of the variety in accordance with the change in growing conditions [10].
The total homeostaticity of varieties $\left(\mathrm{H}_{\mathrm{om}}\right)$ was calculated according to the method of V. V. Khangildin [11, 12].

The variation of the yield trait $\left(\mathrm{H}_{\mathrm{om}}\right)$ was determined by the formula:

$H_{o m}=\frac{\bar{X}^{2}}{\sigma}$,

Where

$\bar{X}$ - arithmetic mean value of the feature;

$\sigma-$ generalized standard deviation.

Breeding value of the variety:

$\left(S_{c}\right)=\bar{X} \times \frac{\bar{X}_{\text {lim }}}{\bar{X}_{\text {opt }}}$

$\bar{X}$ - arithmetic mean value of the feature;

$\bar{X}_{\text {lim }}$ - arithmetic mean limited;

$\bar{X}_{o p t}-$ arithmetic mean is optimal.

Multiplication coefficient $(M C)$. In order to avoid a linear artifact of the regression coefficient, V. A. Dragavtsev introduced a new parameter in 1981 - the multiplication coefficient, which allows comparing the variability of a trait [13]. The higher the numerical value of this coefficient, the more the sign changes:

$$
M C=\frac{X_{i}+b i \times y i}{x_{i}}
$$

Where:

$x_{i}$ - average value of the studied trait in the $i$ variety;

$b i$ - coefficient of linear regression of the $i$-variety;

$y i$ - average value for all averages for all varieties $y i$ for each $j$ point of the experiment.

Index of ecological plasticity (according to the method of A. O. Gryaznov):

$$
\mathrm{IEP}=\frac{\left(\frac{\mathrm{yB}_{1}}{\mathrm{CYO}_{1}} \frac{\mathrm{YB}_{2}}{\mathrm{CYO}}+\ldots+\frac{\mathrm{YB}_{n}}{\mathrm{CYO}}\right)}{n}
$$

$y B_{1}, y B_{2}, y B_{n}$ are the value of the trait in the variety in different years of testing;

$\mathrm{CYO}_{1}, \mathrm{CYO}_{2}, \mathrm{CYO}_{n}$ are the average value of variety trait for each of the variants of the experiment [14].

To determine the adaptive capacity, the variety coefficient of adaptability (CA) was used.

The annual coefficient of adaptability (CA) was calculated using the formula [15]:

$\left.C A=\left(X_{i j}\right) \times 100: X\right): 100$,

where:

$X_{i j}$ - characteristic of a certain variety in the year of testing; $X$ - average varietal value of the trait in a particular year.

The absolute average coefficient of adaptability (CAA) was calculated for the variety by the formula: 
$\left.C A A=\left(X_{i} C\right) \times 100: X_{b}\right): 100$

where:

$X_{i} C$ - average value of the variety trait over the years of testing; $X_{b}$ - long-term average varietal value of the trait.

Stress resistance and compensatory ability of varieties were determined according to A. A. Rossielle and S. Hemblin [16]:

$$
\begin{aligned}
& S R=Y_{\min }-Y_{\max } \\
& C A=\frac{Y_{\min }-Y_{\max }}{2}
\end{aligned}
$$

where:

$Y_{\min }, Y_{\max }$ - the minimum and maximum value of the variety trait.

The coefficient of variation is a relative value that serves to characterize the dispersion (variability) of a trait. It is the ratio of the standard deviation SD to the arithmetic mean, expressed as a percentage:

$$
C V=\frac{S D}{\bar{X}}
$$

The coefficient of variation is used when it is necessary to compare the variability of the features of an object, expressed in different units of measurement [17]. It has meaning exclusively for quantities measured in ratio scales:

$C V<10 \%$ - weak variation;

$C V 11-25 \%$ - average;

$C V>25 \%$ - significant.

Statistical processing of the obtained results was performed with the calculation of the arithmetic mean (x) of the standard deviation (SD), calculated using Microsoft Excel 2016.

\section{Results and discussion}

Such morphological features of basils as plant height, leaf area and bush density not on- ly have a direct impact on crop productivity, but are also used in breeding to create varieties suitable for mechanized harvesting (the higher and denser the bush, the greater its suitability for high-quality mechanized harvesting). For some crops, including basils, a compact (compressed) type of bush branching is preferable, which facilitates inter-row cultivation [18]. Low-growing plants can be used in breeding to create ornamental varieties and varieties intended for growing in confined spaces. Medium-sized and low-growing basil varieties also have greater resistance to lodging, which can be used in breeding for this trait [19].

The dynamics of growth and development of basils (plant height, leaf area, number of leaves and number of first order tillers) at different stages is characterized by the data presented in Table 1. According to the results of the studies, plant height was the least variable sign. All the studied varieties were characterized by low variability of the trait; their indicator was at the level of 3-9\%. In general, the intervarietal variation for this trait was $19 \%$, indicating medium variability.

On the basis of the leaf area, the varieties 'Ametyst', 'Yerevanskyi' and 'Temnyi Opal' turned out to be slightly changing, which had an indicator in the range of $6-10 \%$. Varieties 'Badioryi', 'Mister Barns', 'Lymonnyi Aromat', 'MFI-2', 'Rutan' and 'Siaivo' were moderately changing, where the coefficient of variation was in the range of $11-24 \%$.

In terms of the leaf number, differences were noted between the varieties 'Badioryi', 'Temnyi Opal', 'Ametyst' and 'Siaivo', which were within $21-24 \%$, what indicates the average variability of the trait. Varieties 'Yerevanskyi', 'Mister Barns', 'Lymonnyi Aromat', 'MFI-2' and 'Rutan' were characterized by strong variability

Table 1

\begin{tabular}{|c|c|c|c|c|c|c|c|c|}
\hline \multirow{2}{*}{ Variety } & \multicolumn{2}{|c|}{ Plant height, $\mathrm{cm}$} & \multicolumn{2}{|c|}{ Leaf area, $\mathrm{cm}^{2}$} & \multicolumn{2}{|c|}{ Number of leaves, pcs. } & \multicolumn{2}{|c|}{$\begin{array}{l}\text { Number of first order } \\
\text { tillers, pcs. }\end{array}$} \\
\hline & $\mathrm{x} \pm \mathrm{Sd}$ & $C V, \%$ & $\mathrm{x} \pm \mathrm{Sd}$ & $C V, \%$ & $\mathrm{x} \pm \mathrm{Sd}$ & $C V, \%$ & $\mathrm{x} \pm \mathrm{Sd}$ & $\mathrm{CV}, \%$ \\
\hline ‘Badioryi”* & $58.2 \pm 1.7$ & 3 & $17.78 \pm 2.0$ & 12 & $277.83 \pm 58.3$ & 21 & $9.99 \pm 1.63$ & 16 \\
\hline 'Temnyi Opal' & $59.4 \pm 1.6$ & 3 & $26.69 \pm 2.3$ & 9 & $301.81 \pm 73.2$ & 24 & $10.66 \pm 0.95$ & 9 \\
\hline 'Yerevanskyi' & $46.6 \pm 2.5$ & 6 & $22.69 \pm 2.1$ & 10 & $231.19 \pm 69.4$ & 30 & $9.33 \pm 0.94$ & 10 \\
\hline 'Ametyst' & $35.8 \pm 2.9$ & 8 & $20.40 \pm 1.2$ & 6 & $186.55 \pm 45.2$ & 24 & $6.71 \pm 1.00$ & 15 \\
\hline ‘Mister Barns' & $37.5 \pm 2.3$ & 6 & $14.47 \pm 2.2$ & 16 & $201.21 \pm 55.8$ & 27 & $6.66 \pm 0.94$ & 14 \\
\hline 'Lymonnyi Aromat' & $36.3 \pm 3.2$ & 9 & $14.10 \pm 2.7$ & 19 & $200.87 \pm 56.2$ & 28 & $6.66 \pm 0.94$ & 14 \\
\hline 'MFI-2’ & $39.0 \pm 1.8$ & 5 & $16.87 \pm 3.9$ & 24 & $220.86 \pm 63.7$ & 29 & $7.33 \pm 0.94$ & 13 \\
\hline ‘Rutan' & $44.5 \pm 3.6$ & 8 & $25.06 \pm 2.7$ & 11 & $247.85 \pm 64.6$ & 26 & $8.00 \pm 1.63$ & 20 \\
\hline 'Siaivo' & $53.0 \pm 2.3$ & 4 & $22.43 \pm 2.95$ & 13 & $258.84 \pm 62.8$ & 24 & $8.66 \pm 0.94$ & 11 \\
\hline Xmed. & \multicolumn{2}{|c|}{$\begin{array}{l}45.6 \\
8.80\end{array}$} & \multirow{2}{*}{\multicolumn{2}{|c|}{$\begin{array}{c}20.1 \\
4.27 \\
21\end{array}$}} & \multirow{2}{*}{\multicolumn{2}{|c|}{$\begin{array}{c}236.7 \\
36.03 \\
15\end{array}$}} & \multirow{2}{*}{\multicolumn{2}{|c|}{$\begin{array}{c}8.2 \\
1.43 \\
17\end{array}$}} \\
\hline CV,$\%$ & 19 & & & & & & & \\
\hline
\end{tabular}

Morphometric indicators of basil varieties and the degree of their variability (mean for 2019-2021) 
$(\mathrm{CV}=26-30 \%)$. The most stable varieties 'Temnyi Opal', 'Ametyst' and 'Siaivo', with the coefficient of variation of $24 \%$ were among them.

According to the trait, the number of first order tillers 'Temnyi Opal' and 'Yerevanskyi' varieties, with the indicator of 9 and $10 \%$, turned out to be slightly changing. Other varieties were characterized by medium variability and were at the level of $11-20 \%$.
As a result of the analysis, the group of highly plastic varieties included: 'Mister Barns', 'MFI-2', 'Rutan', 'Siaivo' and 'Badioryi', where the regression coefficient was in the range of 0.91-0.99. Varieties 'Temnyi Opal', 'Yerevanskyi', 'Ametyst' and 'Lymonnyi Aromat' were classified as intensive, their regression coefficient was in the range of 1.03-1.16 (Table 2).

Table 2

\section{Parameters of adaptability of basil varieties depending on plant weight} (mean for 2019-2021)

\begin{tabular}{|l|c|c|c|c|c|c|c|c|}
\hline \multicolumn{1}{|c|}{ Variety } & Xmed. & bi & Hom & Sc & MC & IEP & SR & CA \\
\hline 'Badioryi'* & 303.4 & 0.95 & 1206.11 & 336.64 & 1.84 & 1.14 & -146.59 & 320.14 \\
'Temnyi Opal' & 312.9 & 1.04 & 1283.11 & 347.22 & 1.89 & 1.17 & -159.20 & 332.44 \\
'Yerevanskyi' & 243.8 & 1.06 & 778.83 & 270.52 & 2.17 & 0.90 & -160.70 & 265.23 \\
'Ametyst' & 207.2 & 1.03 & 562.47 & 229.89 & 2.34 & 0.76 & -158.80 & 226.31 \\
'Mister Barns' & 279.4 & 0.91 & 1023.11 & 310.05 & 1.87 & 1.05 & -141.66 & 294.69 \\
'Lymonnyi Aromat' & 226.5 & 1.16 & 672.12 & 251.30 & 2.38 & 0.82 & -177.71 & 248.75 \\
'MFI-2' & 298.0 & 0.93 & 1164.16 & 330.73 & 1.83 & 1.12 & -145.61 & 312.65 \\
'Rutan' & 263.4 & 0.99 & 909.40 & 292.32 & 2.01 & 0.98 & -152.67 & 281.21 \\
'Siaivo' & 282.7 & 0.93 & 1047.62 & 313.75 & 1.88 & 1.06 & -149.65 & 294.69 \\
\hline
\end{tabular}

${ }^{*}$ Xmed. - mean value on the basis of plants; bi - coefficient of linear regression of the variety; Hom - general homeostaticity of the variety; SC - breeding value of the variety; MC - multiplication coefficient; IEP - index of ecological plasticity; SR - stress resistance; CA compensatory ability of varieties.

Medium-plastic varieties were not revealed during the research. Varieties 'Temnyi Opal' (Hom - 1283.11; Sc - 347.22), 'MFI-2' (Hom 1164.16; Sc - 330.73), were characterized by high homeostaticity (Hom) and breeding value (Sc); variety 'Badioryi' also had a high homeostasis (Hom - 1206.11; Sc - 336.64). The highest value of breeding value was noted in variety 'Temnyi Opal' - 347.22, which was significantly higher than the control and other studied varieties. The coefficient of adaptive capacity over the years of research in basil cultivars varied slightly (Table 3 ).

Table 3

Coefficient of adaptability of basil varieties based on plant weight (2019-2021)

\begin{tabular}{|l|c|c|c|c|}
\hline \multirow{2}{*}{ Variety } & \multicolumn{2}{|c|}{$\begin{array}{c}\text { Annual coefficient } \\
\text { of adaptability }\end{array}$} & $\begin{array}{c}\text { Absolute coefficient } \\
\text { of adaptability } \\
\text { (CAA) }\end{array}$ \\
\cline { 2 - 4 } & 2019 & 2020 & 2021 & 1.16 \\
\hline 'Temnyi Opal' & 1.17 & 1.21 & 1.13 & 0.91 \\
'Yerevanskyi' & 0.86 & 0.89 & 0.95 & 0.77 \\
'Ametyst' & 0.72 & 0.70 & 0.84 & 1.04 \\
'Mister Barns' & 1.07 & 1.07 & 1.01 & 0.84 \\
'Lymonnyi Aromat' & 0.78 & 0.77 & 0.93 & 1.11 \\
'MFI-2' & 1.15 & 1.15 & 1.06 & 0.98 \\
'Rutan' & 0.98 & 0.98 & 0.98 & 1.05 \\
'Siaivo' & 1.11 & 1.05 & 1.02 & 1.13 \\
\hline 'Badioryi'* & 1.16 & 1.18 & 1.08 & \\
\hline
\end{tabular}

So, on average, over the years of research, the most adaptive varieties were 'MFI-2' (CAA
$=1.11)$, 'Badioryi' $(\mathrm{CAA}=1.13)$, 'Temnyi Opal' $(\mathrm{CAA}=1.16)$.

Varieties 'Yerevanskyi', 'Mister Barns', 'Rutan' and 'Siaivo' were characterized as moderately adaptive and had an index in the range of 0.91-1.05. Varieties 'Ametyst' and 'Lymonnyi Aromat' proved to be low adaptive $(\mathrm{CAA}=0.77-0.84)$.

As a result of statistical analysis, the group of highly plastic varieties included: 'Temnyi Opal', 'MFI-2', 'Siaivo' and 'Badioryi', where the regression coefficient was in the range of 0.57-0.78. Intensive varieties include: 'Yerevanskyi', 'Ametyst', 'Mister Barns', 'Lymonnyi Aromat' and 'Rutan', where the regression coefficient was in the range of 1.07-1.54. These varieties respond well to improved environmental conditions, so they are best used in intensive growing technologies that provide maximum early production. Medium-plastic varieties were not identified during the research (Table 4).

Varieties 'Temnyi Opal' (Hom - 96.23; Sc 18.02), 'MFI-2' (Hom - 83.67; Sc - 16.80) were characterized by high homeostaticity (Hom) and breeding value (Sc). Variety 'Badioryi' also had a high homeostaticity (Hom 89.55; Sc-17.38). The highest value of breeding value was noted in 'Temnyi opal' variety 18.02, which was significantly higher than the control and other studied varieties. On 
Table 4

Parameters of adaptability of basils depending on the variety in terms of their marketable yield (mean for 2019-2021)

\begin{tabular}{|l|c|c|c|c|c|c|c|c|}
\hline \multicolumn{1}{|c|}{ Variety } & Xmed. & bi & Hom & Sc & MC & IEP & SR & CA \\
\hline 'Badioryi'* & 15.3 & 0.57 & 89.55 & 17.38 & 1.49 & 1.18 & -2.27 & 15.43 \\
'Temnyi Opal' & 15.9 & 0.66 & 96.23 & 18.02 & 1.54 & 1.22 & -2.55 & 16.08 \\
'Yerevanskyi' & 11.9 & 1.14 & 54.48 & 13.56 & 2.25 & 0.91 & -4.25 & 12.43 \\
'Ametyst' & 9.7 & 1.38 & 36.07 & 11.03 & 2.85 & 0.74 & -5.07 & 10.34 \\
'Mister Barns' & 12.9 & 1.07 & 63.94 & 14.69 & 2.08 & 0.99 & -3.99 & 13.40 \\
'Lymonnyi Aromat' & 10.7 & 1.54 & 43.44 & 12.11 & 2.88 & 0.81 & -5.62 & 11.41 \\
'MFI-2' & 14.8 & 0.66 & 83.67 & 16.80 & 1.59 & 1.14 & -2.73 & 14.87 \\
'Rutan' & 12.4 & 1.19 & 58.51 & 14.05 & 2.26 & 0.95 & -4.56 & 12.78 \\
'Siaivo' & 13.8 & 0.78 & 72.50 & 15.64 & 1.74 & 1.06 & -2.96 & 14.08 \\
\hline
\end{tabular}

average, over the years of research, the most adaptive varieties were 'MFI-2' $(\mathrm{CAA}=1.13)$, 'Badioryi' (KAA = 1.17), 'Temnyi Opal' (CAA = 1.22). Varieties 'Yerevanskyi', 'Mister Barns', 'Rutan' and 'Siaivo' were characterized as medium adaptive and had an index in the range of 0.92-1.06. Varieties 'Ametyst' and 'Lymonnyi Aromat' proved to be low adaptive (CAA = 0.74-0.82) (Table 5).

Coefficient of adaptability of basil varieties based on marketable yield (2019-2021)

\begin{tabular}{|l|c|c|c|c|}
\hline \multirow{2}{*}{ Variety } & \multicolumn{2}{|c|}{$\begin{array}{c}\text { Annual coefficient } \\
\text { of adaptability }\end{array}$} & $\begin{array}{c}\text { Absolute } \\
\text { coefficient of } \\
\text { adaptability (CAA) }\end{array}$ \\
\cline { 2 - 4 } & 2019 & 2020 & 2021 & 1.17 \\
\hline 'Badioryi'* & 1.23 & 1.24 & 1.08 & 1.22 \\
'Temnyi Opal' & 1.26 & 1.28 & 1.13 & 0.92 \\
'Yerevanskyi' & 0.89 & 0.89 & 0.95 & 0.74 \\
'Ametyst' & 0.69 & 0.68 & 0.84 & 0.99 \\
'Mister Barns' & 0.98 & 0.99 & 1.01 & 0.82 \\
'Lymonnyi Aromat' & 0.75 & 0.75 & 0.93 & 1.13 \\
'MFI-2' & 1.19 & 1.17 & 1.06 & 0.95 \\
'Rutan' & 0.94 & 0.91 & 0.98 & 1.06 \\
\hline 'Siaivo' & 1.07 & 1.09 & 1.02 & \\
\hline
\end{tabular}

\section{Conclusions}

The study of productivity, variability of morphometric parameters, adaptive properties of basil varieties made it possible to identify the best of them for the conditions of the Right-Bank Forest-Steppe of Ukraine. According to the results of the research, the following varieties can be attributed to the group of highly plastic ones on the basis of "commercial yield" trait: 'Temnyi Opal', 'MFI-2', 'Siaivo' and 'Badioryi', for which the regression coefficient was in the range of 0.57-0,78. Varieties 'MFI-2' (CAA = 1.11), 'Badioryi' (CAA = 1.13), 'Temnyi Opal' $(\mathrm{CAA}=1.16)$ turned out to be the most adaptive based on the trait "plant weight»; varieties 'Badioryi' $(\mathrm{CAA}=1.17)$, 'Temnyi Opal' (CAA $=1.16$ ), and 'MFI-2' $(\mathrm{CAA}=1.13)-$ according to the trait $« \mathrm{com}$ - mercial yield». An analysis of the combination of high productivity, quantitative characteristics of the crop structure with the level of ecological plasticity and stability indicates different ways of forming these indicators in individual varieties. It was revealed that a high level of plasticity and yield stability does not give a similar result in terms of individual quantitative characteristics of its structure.

\section{References}

1. Teliban, G., Stoleru, V., Marian, B., Andrei, L., Munteanu, N., Popa, L., \& Caruso, G. (2020). Biochemical, Physiological and Yield Characteristics of Red Basil as Affected by Cultivar and Fertilization. Agriculture, 10, Article 48. doi: 10.3390/agriculture10020048

2. Cavar Zeljkovic, S., Komzáková, K., Šišková, J., Karalija, E., Smekalova, K., \& Tarkowski, P. (2020). Phytochemical variability of selected basil genotypes. Industrial Crops and Products, 157, Article 112910. doi: 10.1016/j.indcrop.2020.112910

3. Ulianych, 0., Kucher, I., \& Rudiuk, V. (2020). Term of cultivation of cassette seedlings of cornflowers real. In Nauka, tendentsii ta perspektyvy ovochivnytstva v Ukraini: VIII Vseukrainska naukovo-praktychna internet-konferentsiia [Science, trends and prospects of vegetable growing in Ukraine: VIII All-Ukrainian scientific-practical Internet-conference] (pp. 18-20). Uman: N. p. [in Ukrainian]

4. Marian, B., Jeliazkov, V., Dincheva, I., Andrei, L., \& Teliban, G. (2018). Fertilization modifies the essential oil and physiology of basil varieties. Industrial Crops and Products, 121, 282-293. doi: 10.1016/j.indcrop.2018.05.021

5. Dzida, K. (2010). Biological value and essential oil content in sweet basil (Ocimum basilicum L.) depending on calcium fertilization and cultivar. Acta Scientiarum Polonorum Hortorum Cultus, 9(4), 153-161.

6. Mahmoudi, H., Marzouki, M., Mrabet, Y., Mezni, M., Ait Ouazzou, A., \& Hosni, K. (2020). Enzyme pretreatment improves the recovery of bioactive phytochemicals from sweet basil (Ocimum basilicum L.) leaves and their hydrodistilled residue byproducts, and potentiates their biological activities. Arabian Journal of Chemistry, 13(8), 6451-6460. doi: 10.1016/j.arabjc.2020.06.003

7. Shirazi, M., Gholami, H., Kavoosi, G., Rowshan, V., \& Tafsiry, A. (2014). Chemical composition, antioxidant, antimicrobial and cytotoxic activities of Tagetes minuta and Ocimum basilicum essential oils. Food Science \& Nutrition, 2(2), 146-155. doi: $10.1002 /$ fsn3.85

8. Saude, C., Westerveld, S., Filotas, M., \& Mcdonald, M. (2013). Comparison of basil varieties and fungicides for management of basil downy mildew in Ontario. Canadian Journal of Plant Pathology, 35, 124-124. 
9. Kucher, I., Ulianich, 0., \& Yatsenko, V. (2021). Efficiency of application of different forms of superabsorbents in crops of basil. Scientific Horizons, 24(1), 45-53. doi: 10.48077/scihor.24(1).2021.45-53

10. Eberhart, S. A., \& Russell, W. A. (1966). Stability parameters for comparing varieties. Crop Science, 6(1), 36-40. doi: 10.2135/ cropsci1966.0011183X000600010011x

11. Khangildin, V. V. (1978). On the principles of modeling varieties of intensive type. In Genetika kachestvennyh priznakov sel'skohozyaystvennyh rasteniy [Genetics of qualitative traits of agricultural plants] (pp. 111-116). Moscow: Nauka. [in Russian]

12. Khangildin, V. V. (1984). Problems of breeding for homeostasis and problems of the theory of the breeding process in plants. In Selektsiya, semenovodstvo i sortovaya agrotekhnika $v$ Bashkirii [Selection, seed production and varietal agricultural technology in Bashkiria] (pp. 111-116). Ufa: N. p. [in Russian]

13. Dragavtsev, V. A., Tsilke, V. A., \& Reiter, B. G. (1984). Genetika priznakov produktivnosti yarovoy pshenitsy $v$ Zapadnoy Sibiri [Genetics of productivity traits of spring wheat in Western Siberia]. Novosibirsk: Nauka. [in Russian]

14. Gryaznov, A. A. (1996). Karabal'skiy yachmen [Karabal barley]. Kustanay: Pechatnyy dvor. [in Russian]

15. Zhivotkov, l. A., Morozova, Z. A., \& Sekatyeva, L. I. (1994). Methods for identifying potential productivity and adaptability of varieties and breeding forms of winter wheat in terms of yield. Selektsiya i semenevodstvo [Plant Breeding and Seed Production], 2, 3-6. [in Russian]

16. Rossielle, A. A., \& Hemblin, J. (1981). Theoretical aspects of selection for yield in stress and non-stress environments. Crop Science, 21(6), 27-29. doi: 10.2135/cropsci1981.0011183X00 2100060033x

17. Gorova, T. K., \& Yakovenko, K. I. (Eds.). (2001). Suchasni metody selektsii ovochevykh i bashtannykh kultur [Modern methods of selection of vegetable and melon crops]. Kharkiv: Osnova. [in Ukrainian]

18. Chisnicean, L. (2019). Some results selection of basil (Ocimum basilicum L.) in the conditions of the republic of Moldova. Ovoshchi Rossii [Vegetable Crops of Russia], 3, 18-20. doi: 10.18619/2072-9146-2019-3-18-20 [in Russian]

19. Sachivko, T. V. (2014). Otsenka iskhodnogo materiala bazilika (Ocimum L.) $i$ ego ispol'zovanie $v$ selektsii [Evaluation of the source material of the basil (Ocimum L.) and its use in breeding] (Cand. Agric. Sci. Diss.). Belarusian State Agricultural Academy, Gorki, Belarus. [in Russian]

\section{Використана література}

1. Teliban G., Stoleru V., Marian B. et al. Biochemical, Physiological and Yield Characteristics of Red Basil as Affected by Cultivar and Fertilization. Agriculture. 2020. Vol. 10, Iss. 2. 48. doi: 10.3390/agriculture10020048

2. Cavar Zeljkovic S., Komzáková K., Šišková J. et al. Phytochemical variability of selected basil genotypes. Industrial Crops and Products. 2020. Vol. 157. 112910. doi: 10.1016/j.indcrop.2020.112910

3. Улянич 0. I., Кучер I. 0., Рудюк В. М. Строк вирощування касетної розсади васильків справжніх. Наука, тенденції та перспективи овочівництва в Україні : VIII Всеукраїнська науково-практична інтернет-конференція (м. Умань, 12 червня 2020 р.). Умань, 2020. С. 18-20.
4. Marian B., Jeliazkov V., Dincheva I. et al. Fertilization modifies the essential oil and physiology of basil varieties. Industrial Crops and Products. 2018. Vol. 121. P. 282-293. doi: 10.1016/ j.indcrop.2018.05.021

5. Dzida K. Biological value and essential oil content in sweet basil (Ocimum basilicum L.) depending on calcium fertilization and cultivar. Acta Scientiarum Polonorum Hortorum Cultus. 2010. Vol 9, Iss. 4. P. 153-161.

6. Mahmoudi H., Marzouki M., Mrabet Y. et al. Enzyme pretreatment improves the recovery of bioactive phytochemicals from sweet basil (Ocimum basilicum L.) leaves and their hydrodistilled residue by-products, and potentiates their biological activities. Arabian Journal of Chemistry. 2020. Vol. 13, Iss. 8. P. 6451-6460. doi: 10.1016/j.arabjc.2020.06.003

7. Shirazi M. T., Gholami H., Kavoosi G. et al. Chemical composition, antioxidant, antimicrobial and cytotoxic activities of $\mathrm{Ta}$ getes minuta and Ocimum basilicum essential oils. Food Science \& Nutrition. 2014. Vol. 2, Iss. 2. P. 146-155. doi: $10.1002 /$ fsn3.85

8. Saude C., Westerveld S., Filotas M. et al. Comparison of basil varieties and fungicides for management of basil downy mildew in Ontario. Canadian Journal of Plant Pathology. 2013 Vol. 35. P. 124-124.

9. Kucher I., Ulianich 0., Yatsenko V. Efficiency of application of different forms of superabsorbents in crops of basil. Scientific Horizons. 2021. Vol. 24, Iss. 1. P. 45-53. doi: $10.48077 /$ scihor.24(1).2021.45-53

10. Eberhart S. A., Russell W. A. Stability parameters for comparing varieties. Crop Science. 1966 Vol. 6, Iss. 1. P. 36-40. doi: 10.2135/cropsci1966.0011183X000600010011x

11. Хангильдин В. В. 0 принципах моделирования сортов интенсивного типа. Генетика количественных признаков сельскохозяйственных растений. Москва : Наука, 1978. С. 111-116.

12. Хангильдин В. В. Проблемы селекции на гомеостаз и вопросы теории селекционного процесса у растений. Селекция, семеноводство и сортовая агротехника в Башкирии. Уфа, 1984. C. 102-123.

13. Драгавцев В. А., Цильке В. А., Рейтер Б. Г. Генетика признаков продуктивности яровой пшеницы в Западной Сибири. Новосибирск : Наука, 1984. 229 с.

14. Грязнов А. А. Карабальский ячмень. Кустанай : Печат. двор, 1996. $448 \mathrm{C}$.

15. Животков Л. А., Морозова 3. А., Секатуева Л. И. Методика выявления потенциальной продуктивности и адаптивности сортов и селекционных форм озимой пшеницы по показателю урожайности. Селекция и семеноводство. 1994. № 2. С. 3-6.

16. Rossielle A. A., Hemblin J. Theoretical aspects of selection for yield in stress and non-stress environments. Crop Science. 1981. Vol. 21, Iss. 6. P. 27-29. doi: 10.2135/cropsci1981.001 $1183 \times 002100060033 \mathrm{x}$

17. Сучасні методи селекції овочевих і баштанних культур / Т. К. Горова, К. І. Яковенко. Харків : Основа, 2001. С. 287302.

18. Кисничан Л. Некоторые результаты селекции базилика (Ocimum basilicum L.) в условиях республики Молдова. Овощи России. 2019. № 3. С. 18-20. doi: 10.18619/2072-9146-20193-18-20

19. Сачивко Т. В. Оценка исходного материала базилика (Ocimum L.) и его использование в селекции : дис. ... канд. с.-х. наук : 06.01.05 / Белорус. гос. с.-х. акад. Горки, 2014. 143 с. 
УДК 631.526.1/8:262:635.71(477.46)

Кучер I. О. Адаптивна мінливість сортів васильків справжніх (Ocimum basilicum L.). Plant Varieties Studying and Protection. 2021. T. 17, № 4. C. 267-273. https://doi.org/10.21498/2518-1017.17.4.2021.248975

Уманський національний університет садівництва, вул. Інститутська, 1, м. Умань, 20301, Україна, e-mail: inna.kucher95@gmail.com

Мета. Оцінювання стану сортових ресурсів і адаптивнопродуктивного потенціалу рослин васильків справжніх (базиліку). Методи. Польові, лабораторні, статистичні i розрахунково-аналітичні. До польових належали розбивка дослідної ділянки та польові роботи. Лабораторний метод застосовували для аналізу рослин, оцінювання якості врожаю, дослідження фізичних, хімічних та мікробіологічних властивостей ґрунту. Статистичним та розрахунково-аналітичним методами обчислювали результати. Результати. За результатами досліджень до групи високопластичних сортів за ознакою «товарна врожайність» було віднесено сорти 'Темний опал', 'МФI-2', 'Сяйво' та 'Бадьорий', де коефіцієнт регресії був у межах 0,57-0,78. Найвище значення селекційної цінності за о3накою «маса рослин» було відзначено у сорту 'Темний опал', $\mathrm{Sc}=347,22$. До групи високопластичних сортів за ознакою «маса рослин» було віднесено сорти 'Містер Барнс', 'МФI-2', 'Рутан', 'Сяйво' та 'Бадьорий', для яких коефіцієнт регресії був у межах 0,91-0,99. До інтенсивних віднесли сорти 'Темний опал', 'Єреванський', 'Аметист' та 'Лимонний аромат'. Показник коефіцієнту регресії для цих сортів знаходився у межах 1,03-1,16. Аналіз поєднання високої продуктивності, кількісних ознак структури врожаю 3 рівнем екологічної пластичності та стабільності свідчить про різні шляхи формування цих показників окремих сортів. Встановлено, що високий рівень пластичності та стабільності врожайності не гарантує аналогічного результату за окремими кількісними ознаками його структури. Висновки. За величиною параметрів варіювання ознак можна оцінювати ступінь адаптивності сортів васильків справжніх. Отримані результати дозволять об'єктивно оцінити адаптивно-продуктивний потенціал сортів та якісно провести добір вихідних форм для подальшої селекції на адаптивність.

Ключові слова: адаптивна здатність; стабільність; пластичність; морфометричні показники; урожайність.

Надійшла / Received 26.10.2021 Погоджено до друку / Accepted 23.11.2021 